\title{
Indigenous animal production practices in Santhal Pargana region of Jharkhand
}

\author{
VEERESH KUMAR AND M.N. ANSARI
}

\begin{abstract}
Indigenous knowledge is passed down from generation to generation, usually by word of mouth and provides a valuable resource for sustainable agricultural development. The study was carried out in Dumka district of Santhal Pargana region in the state of Jharkhand. The sample consisted of 150 farmer respondents. The results revealed that the farmer belonging to agriculturally less progressive villages were found to be using more number of ITK in comparison to those of progressive villages. The results also reported that ITK practices mentioned at Sr. number 1 and 3 (For land preparation and pre-sowing), Sr. number 2 (for soil treatment), Sr. number 2 (for sowing), Sr. number 1 and 2 (For nursery raising and transplanting) and Sr. number 3 (for inter culturing and weed management) were found to be used by majority of the respondents in both the agriculturally progressive and less progressive villages.
\end{abstract}

KEY WORDS : Attributes, ITK, Animal production practices

HOW TO CITE THIS PAPER : Kumar, Veeresh and Ansari, M.N. (2015). Indigenous animal production practices in Santhal Pargana region of Jharkhand. Res. J. Animal Hus. \& Dairy Sci., 6(1) : 12-15. MUZAFFARPUR (BIHAR) INDIA

\section{Associated Authors':}

M.N. Ansari, Department of Extension Education, Tirhut College of Agriculture, Dholi, MUZAFFARPUR (BIHAR) INDIA 